\title{
Effect of electrical cure of concrete on maturity and compressive strength
}

\section{Efecto de la curación eléctrica del concreto en la madurez y la resistencia a la compresión}

İsmail Hocaoğlu (Main and Corresponding Author)

Afyon Kocatepe University, Engineering Faculty, Civil Engineering Department

03200, Afyonkarahisar (Turkey)

afyonbeton@hotmail.com

\section{Tayfun Uygunoğlu}

Afyon Kocatepe University, Engineering Faculty, Civil Engineering Department

03200, Afyonkarahisar (Turkey)

uygunoglu@aku.edu.tr

Manuscript Code: 1082

Date of Acceptance/Reception: 21.06.2019/28.02.2018

DOI: 10.7764/RDLC.18.2.214

\begin{abstract}
In this study, the effects of concretes which have $250,300,350$ and $400 \mathrm{~kg} / \mathrm{m}^{3}$ cement in per $\mathrm{m}^{3}$ and different voltage level application $(0 \mathrm{~V}, 40 \mathrm{~V}, 60$ $\mathrm{V}, 80 \mathrm{~V}$ and $100 \mathrm{~V} \mathrm{AC}$ ) on concrete maturity have been investigated. It has been researched if there is relationship with maturity and compressive strength on the concrete to which stress intensity has been applied. The electrical current has been applied on fresh concretes for 24 hours whose sizes are $10 \times 10 \times 35 \mathrm{~cm}$. Their internal temperatures of concretes have been recorded and maturity values have been calculated. It has been concluded that $\mathrm{AC}$ stress intensity can be used to accelerate maturity through obtaining optimum degree on concrete's internal temperature without any compressive strength lost.
\end{abstract}

Keywords: Dosage, concrete, electrical cure, maturity, ac current.

Resumen

En este estudio, se investigaron los efectos de los hormigones que tienen 250, 300, 350 y $400 \mathrm{~kg} / \mathrm{m}^{3}$ de cemento y la aplicación de diferentes niveles de voltaje $(0 \mathrm{~V}, 40 \mathrm{~V}, 60 \mathrm{~V}, 80 \mathrm{~V}$ y $100 \mathrm{~V}$ AC) en la madurez del concreto. Se ha investigado si existe una relación con la madurez y la resistencia a la compresión en el concreto al que se ha aplicado la intensidad de tensión. La corriente eléctrica se ha aplicado sobre hormigones frescos durante 24 horas cuyos tamaños son $10 \times 10 \times 35 \mathrm{~cm}$. Se han registrado las temperaturas internas de los hormigones y se han calculado los valores de madurez. Se ha llegado a la conclusión de que la intensidad de tensión de CA se puede utilizar para acelerar la madurez a través de la obtención de un grado óptimo en la temperatura interna del concreto sin pérdida de resistencia a la compresión.

Palabras clave: Dosificación, hormigón, cura eléctrica, madurez, corriente AC.

Introduction

The concept of maturity is a method which plays a role in concrete's gaining strength and this method is measured through defining the relation between temperature and time. This method can be used to predict compressive strength of concretes which are poured into the mould during production phase in the following days. Maturity degree as a factor which defines concrete's hardening situation is used as a non-damaged method for prediction of concrete's strength (Hu, 2014).

Maturity method can be used for temperature-time effects on strength development. In order to use maturity method, the relation between strength and maturity which is going to be used in concrete should be identified. Maturity can be calculated through continuously observing temperature history of the concrete which is poured into the mould during casting stage. Compressive strength is the most important feature of concrete. Other features of concrete such as tensile strength, flexural strength, elasticity models, water tightness and durability are related with compressive strength (Wang \& Park, 2017). According to age and temperature of the concrete, the maturity approach is often used to predict compressive strength (Carino \& Lew, 2001). Saul, who proposed the principle of maturity, declares that compressive strength can be changed according to the curing of concrete under different temperatures through having the same maturity (Saul, 1951). Bergstrom (1951) found out that maturity method could be applied to concretes in which the datum temperature was redefined. He also showed that maturity method was valid for normal curing temperatures. The hydration of cement particles depends upon both the characteristic features of components and environmental factors (Massazza \& Daimond, 1992; Çakir \& Aköz, 2008). When the temperature of curing rises, great changes on reaction kinetics, microstructure porosity and hydration degree in cement pastes have been 
observed (Frías, 2006; Frías Rojas, 2006). Several studies have been conducted to elucidate the influence of combined effect of age, curing temperature and electrical cure on different mechanisms involved during cement hydration. Topçu et al. (2012) applied DC current to cement pastes which had different water/cement ratio $(0.40,0.45,0.50$, $0.55)$, different mineral admixtures (fly ash, silica fume and blast furnace slag) and different ratio by weight $(0 \%, 10 \%$, $20 \%, 30 \%$ ). As a result of their study, applying electric current can be used for obtaining rapid setting time on the cement paste with high volume mineral admixture. Uygunoglu and Hocaoglu (2018) found that the duration of final setting time was shortened as the amount of cement in concrete and the voltage level increased. Kjellsen et al. (1990) examined the microstructure of cement pastes hydrated at temperatures ranging from 5 to $50{ }^{\circ} \mathrm{C}$; they found out that a uniform distribution of hydration product for cement had been occurred at the low temperatures while a nonuniform hydration products for cement cured had been occurred at the high temperatures. Maekawa et al. (2009) developed a multi-component hydration model and evaluated the hygrothermo-mechanical development of hardening concrete at different curing temperatures. Laplante et al. (1998)_proposed a maturity technique which is based on general law of chemical reactions acceleration depending on the temperature. According to Benaicha et al. (2016) compressive strength of concrete can be predicted through calculation of maturity. Xuan et al. (2018) proposed a model based on the maturity method which may precisely predict compressive strength of the carbonated concrete blocks.

\section{Description of the problem}

In this study, the effect of amount of cement in concrete and voltage level of concrete on maturity and compressive strength of concrete at the end of 1 day, 28 and 180 days have been investigated. It has been also researched if a relationship can be established between maturity and compressive strength of the concretes to which stress intensity has been applied.

\section{Materials and methods}

In the experimental study, crushed sand and coarse aggregate have been used. Specific gravity of crushed sand and coarse aggregate are 2.67 and 2.70, the maximum grain sizes are $4 \mathrm{~mm}$ and $11.2 \mathrm{~mm}$. In the experiments, CEM I 42.5 R cement which is suitable to TS EN 197-I standards have been used (TS EN 933-2, 2013).

\section{Production of specimen}

Concretes have been produced through using 250,300, 350 and $400 \mathrm{~kg}$ cement in $1 \mathrm{~m}^{3}$ concrete and water/cement ratio of these concretes is 0.65 . The 25 liter capacity mixer has been used. Then they have been put in electrically isolated plastic moulds whose sizes are $10 \mathrm{~cm} \times 10 \mathrm{~cm} \times 35 \mathrm{~cm}$. Unit volumes components of concretes which has 250 , $300,350,400 \mathrm{~kg} / \mathrm{m}^{3}$ cement are shown in Table 1.

\begin{tabular}{ccccc}
\hline $\begin{array}{c}\text { Sample } \\
\text { Code }\end{array}$ & Cement $\mathrm{kg} / \mathrm{m}^{3}$ & $\begin{array}{c}\text { Water } \\
\mathrm{kg} / \mathrm{m}^{3}\end{array}$ & $\begin{array}{c}\text { Crushed sand, } \\
\mathrm{kg} / \mathrm{m}^{3}\end{array}$ & $\begin{array}{c}\text { Coarse } \\
\text { Aggregate } \\
\mathrm{kg} / \mathrm{m}^{3}\end{array}$ \\
\hline M1 & 250 & 162.5 & 962 & 984 \\
M2 & 300 & 195 & 875 & 887 \\
M3 & 350 & 227 & 852 & 858 \\
M4 & 400 & 260 & 772 & 789 \\
\hline
\end{tabular}

Initially for the mixture of concrete, crushed sand, coarse aggregate and cement were mixed for 1 minute in order to have dry mixture. Then almost $2 / 3$ of mixture water was added to the dry mixture. Finally the rest $(1 / 3)$ of water were put into the mixture and the process of mixing was continued for 5 minutes. Prepared concretes were put into plastic moulds whose sizes are $10 \mathrm{~cm} \times 10 \mathrm{~cm} \times 35 \mathrm{~cm}$. One day's specimens haven't been cured at water. 28 days and 180 days specimens have been cured at water during 27 days. Then $0 \mathrm{~V}, 40 \mathrm{~V}, 60 \mathrm{~V}, 80 \mathrm{~V}$ and $100 \mathrm{~V}$ stress were applied to all concretes by alternative current (AC) power- supply source for 24 hours. In order to apply stress intensity to specimens, two copper electrodes were used. 


\section{Preparation of experiment set up}

For applying stress intensity to the specimens, an AC power-supply source and graphtech mark data logger which has 10 canal capacities have been used. Power supply was directly connected to the specimens to apply AC current. Data logger is used to evaluate the temperature of specimens and data is recorded at every 10 minutes. A view of concrete to which electrical current applied has been shown in Figure 1.

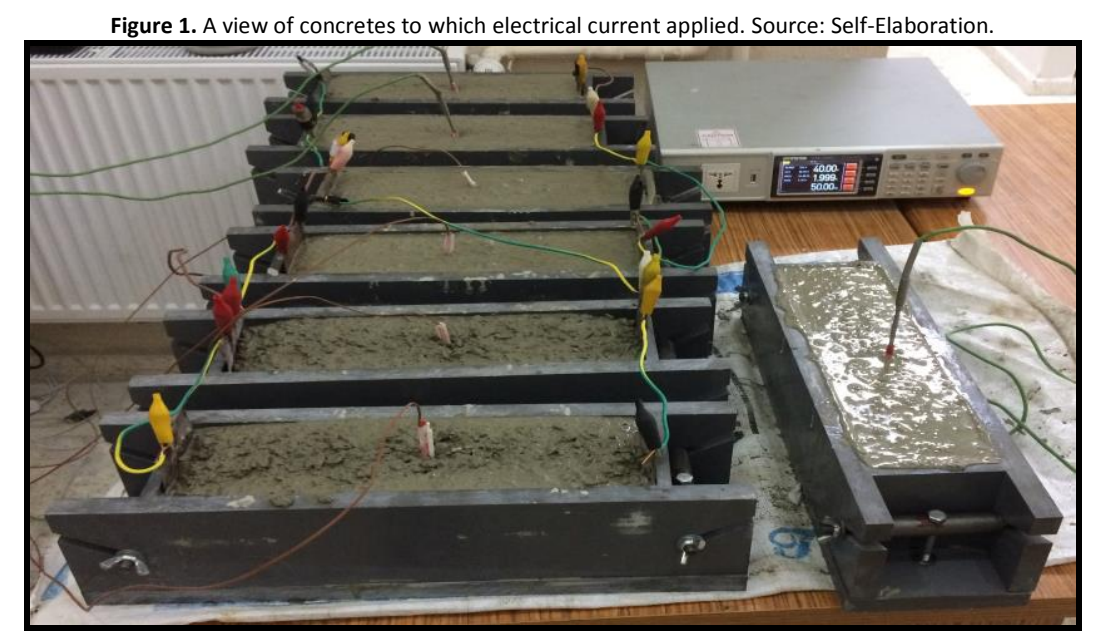

Internal temperatures of concretes are recorded in every 10 minutes from the beginning of hydration till hardening and maturity has been calculated. Maturity of concrete is calculated as follows.

$$
M=\sum_{0}^{t}\left(T-T_{o}\right) \Delta t
$$

Where, $\mathrm{M}$ is maturity index $\left({ }^{\circ} \mathrm{C}\right.$-hour or ${ }^{\circ} \mathrm{C}$-day), $\mathrm{T}$ is mean temperature of concrete in $\Delta \mathrm{t}$ time span $\left({ }^{\circ} \mathrm{C}\right), \mathrm{T}_{0}$ is used -10 ${ }^{0} \mathrm{C}$ at the beginning point and $\mathrm{t}$ is passed time (day or hour), (Saul, 1951).

\section{The impact of dosage and voltage level on maturity}

At ASTM C1074-11 (2015), it has been identified that maturity can be calculated between $10{ }^{\circ} \mathrm{C}-45{ }^{\circ} \mathrm{C}$ temperature of concrete. In order to research the effect of dosage and voltage level on maturity, maturity of concretes has been compared through applying stress to the concretes which have stable w/c ratio (0.65) and $10 \times 10 \times 35 \mathrm{~cm}$ size. $0 \mathrm{~V}, 40$ $\mathrm{V}, 60 \mathrm{~V}, 80 \mathrm{~V}$ and $100 \mathrm{~V} \mathrm{AC}$ current have been applied to the concretes which have $250,300,350,400 \mathrm{~kg} / \mathrm{m}^{3} \mathrm{cement}$ at stable frequency $(50 \mathrm{~Hz})$ from the beginning of hydration. For the concretes which have $250,300,350,400 \mathrm{~kg} / \mathrm{m}^{3}$ cement, maturity values of the concretes to which electric current is applied are measured higher than the ones to which electric current is not applied (Figures 2-5).

When stress intensity has been applied to the concretes which have $250,300,350$ and $400 \mathrm{~kg} / \mathrm{m}^{3}$ cement, it has been observed that concretes obtain maturity at shorter time than the reference specimens. When voltage level increased (from 0 to $100 \mathrm{~V}$ ) at concretes which have $250-400 \mathrm{~kg} / \mathrm{m}^{3}$ cement content, maturity of concretes were increases too. When the maturity levels of concretes which have $250,300,350$ and $400 \mathrm{~kg} / \mathrm{m}^{3}$ cement have been compared, it has been seen that concrete obtain maturity at a shorter time as the amount of cement increases. In Table 2, 500 minutes of maturity of concretes, which have $250,300,350$ and $400 \mathrm{~kg} / \mathrm{m}^{3}$ cement, to which different stress intensity has been applied is shown. 
Figure 2. Maturity of concrete with cement content at $250 \mathrm{~kg} / \mathrm{m}^{3}$.Source: Self-Elaboration.

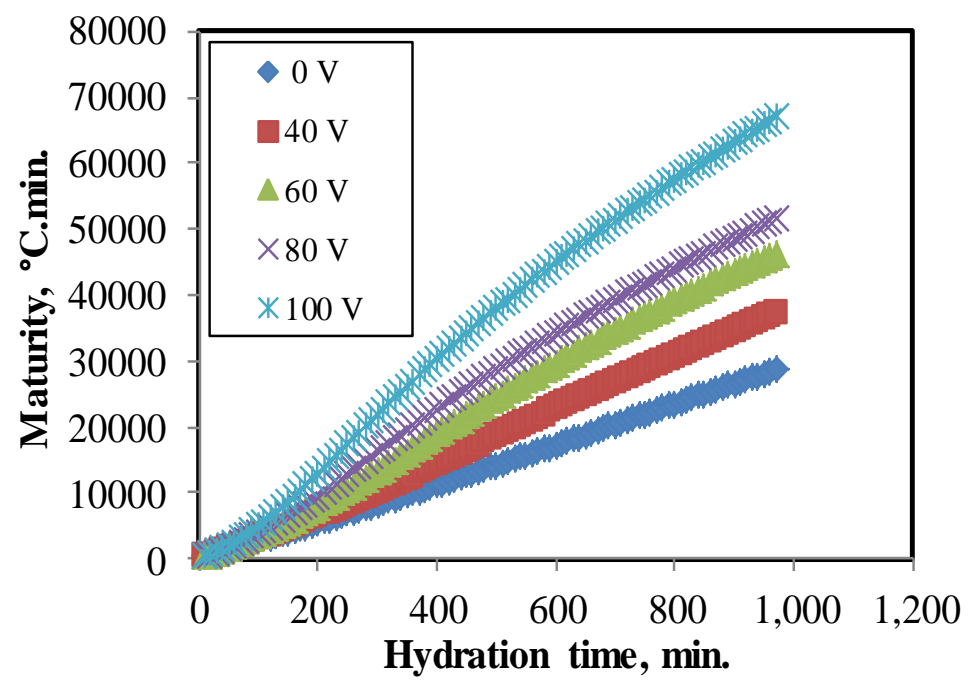

Figure 3. Maturity of concrete with cement content at $300 \mathrm{~kg} / \mathrm{m}^{3}$. Source: Self-Elaboration.

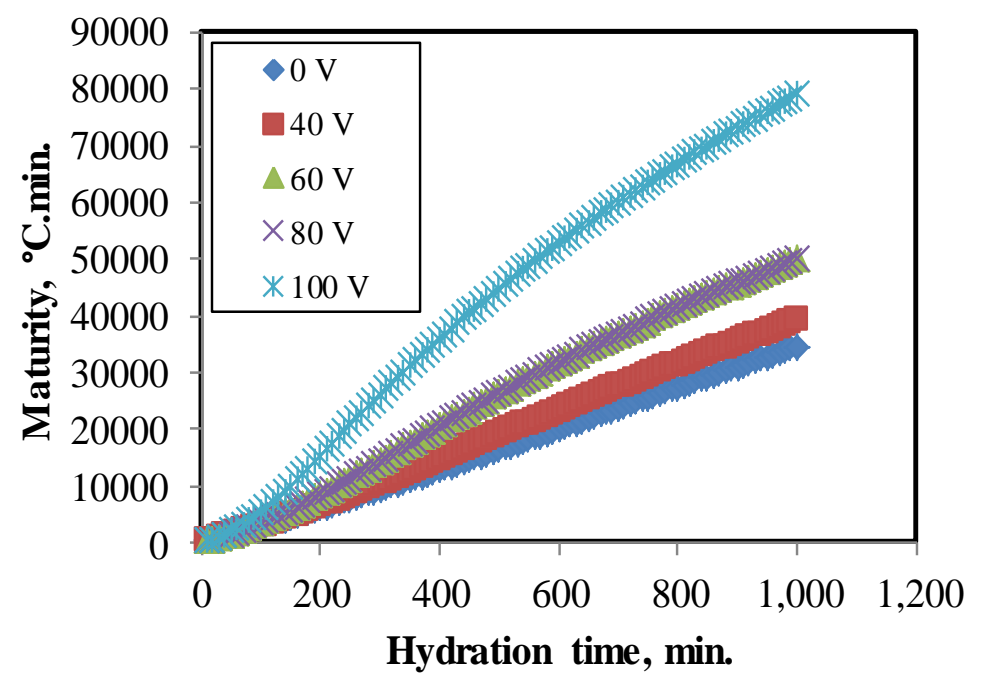

Figure 4. Maturity of concrete with cement content at $350 \mathrm{~kg} / \mathrm{m}^{3}$. Source: Self-Elaboration.

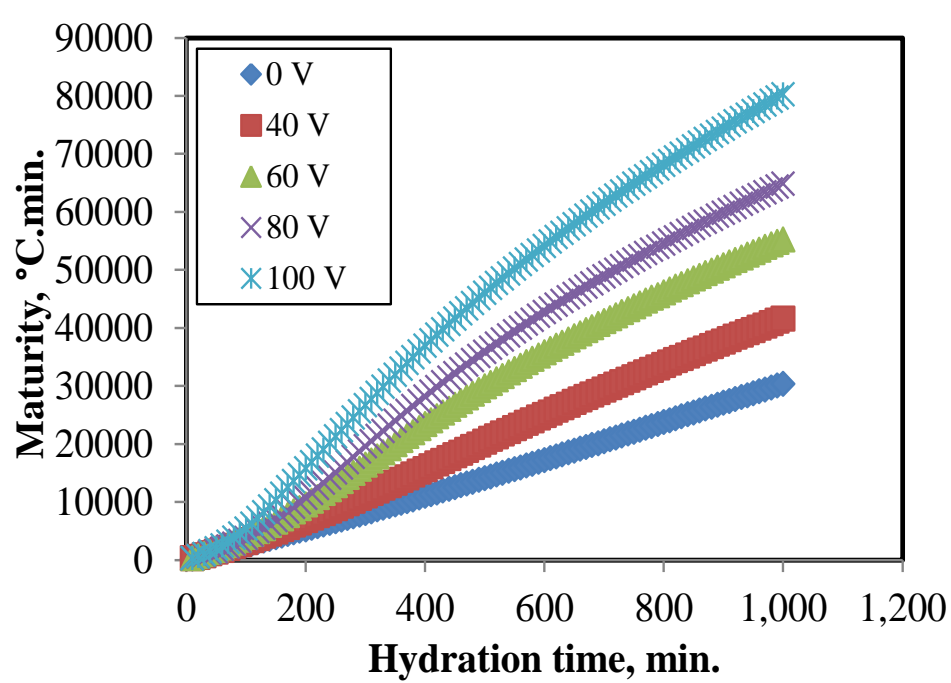




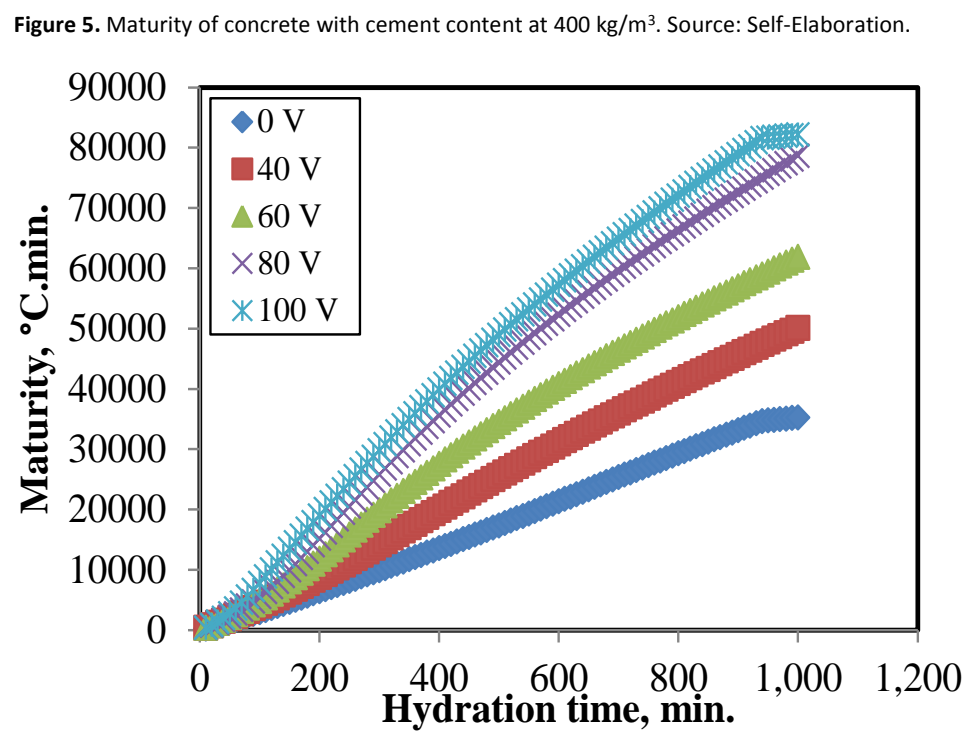

\begin{tabular}{|c|c|c|c|c|}
\hline $\begin{array}{l}\text { Sample } \\
\text { Code }\end{array}$ & $\begin{array}{l}\text { Dosage } \\
\left(\mathrm{Kg} / \mathrm{m}^{3}\right)\end{array}$ & $\begin{array}{l}\text { Voltage } \\
\text { Level } \\
\text { (V) }\end{array}$ & $\begin{array}{l}\text { Maturity } \\
\text { (OC.min) }\end{array}$ & $\begin{array}{c}1 \text { Day } \\
\text { Compressive } \\
\text { Strength (MPa) }\end{array}$ \\
\hline M1 & 250 & - & 14145 & 12.29 \\
\hline M2 & 250 & 40 & 18554 & 15.01 \\
\hline M3 & 250 & 60 & 24447 & 15.09 \\
\hline M4 & 250 & 80 & 28675 & 16.02 \\
\hline M5 & 250 & 100 & 37919 & 22.63 \\
\hline M6 & 300 & - & 16434 & 13.27 \\
\hline M7 & 300 & 40 & 19051 & 15.14 \\
\hline M8 & 300 & 60 & 26342 & 15.81 \\
\hline M9 & 300 & 80 & 26364 & 17.94 \\
\hline M10 & 300 & 100 & 44792 & 20.50 \\
\hline M11 & 350 & - & 14076 & 14.29 \\
\hline M12 & 350 & 40 & 20381 & 16.92 \\
\hline M13 & 350 & 60 & 29882 & 17.46 \\
\hline M14 & 350 & 80 & 35874 & 16.48 \\
\hline M15 & 350 & 100 & 46000 & 17.30 \\
\hline M16 & 400 & - & 17352 & 16.27 \\
\hline M17 & 400 & 40 & 25550 & 16.57 \\
\hline M18 & 400 & 60 & 34467 & 18.16 \\
\hline M19 & 400 & 80 & 44354 & 18.36 \\
\hline M20 & 400 & 100 & 48958 & 18.32 \\
\hline
\end{tabular}




\section{The relationship between maturity and compressive strength of concrete}

In order to establish relation between 1 day maturity (at the end of 1440 minutes) and 1 day compressive strength in terms of voltage level on concretes $(0 \mathrm{~V}, 40 \mathrm{~V}, 60 \mathrm{~V}, 80 \mathrm{~V}, 100 \mathrm{~V})$, graphics have been prepared (Figures 6 - 9). In Figures $6-9, X$ axis represents maturity and $Y$ axis represents 1 day compressive strength. As a result of forming trend line, equations of compressive strength have been obtained depending on the maturity of the concretes which have $250,300,350,400 \mathrm{~kg} / \mathrm{m}^{3}$ cement. Hence, it has been concluded that maturity of concretes can be calculated through measuring internal temperatures of concretes. Compressive strength of concretes can be approximately identified through determining maturity. Relationship between maturity and 1 day compressive strength of the concretes which have $250,300,350,400 \mathrm{~kg} / \mathrm{m}^{3}$ cement can be calculated as given in Table 3 .

Figure 6. Relationship between maturity and 1 day compressive strength of concrete, $250 \mathrm{~kg} / \mathrm{m}^{3}$ cement Source: Self-Elaboration.

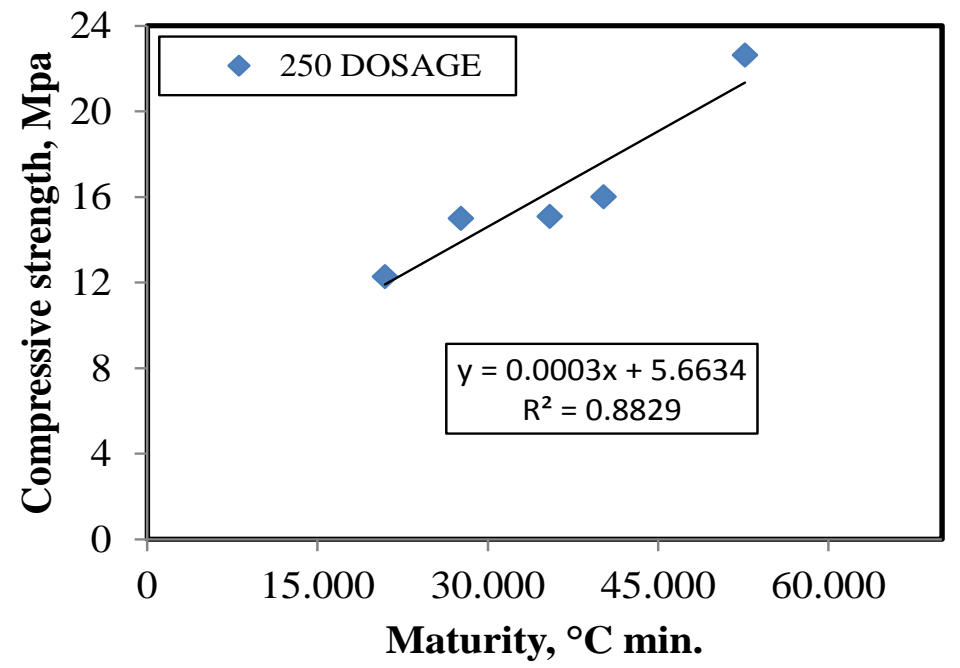

Figure 7. Relationship between maturity and 1 day compressive strength of concrete, $300 \mathrm{~kg} / \mathrm{m}^{3}$ cement. Source: Self-Elaboration.

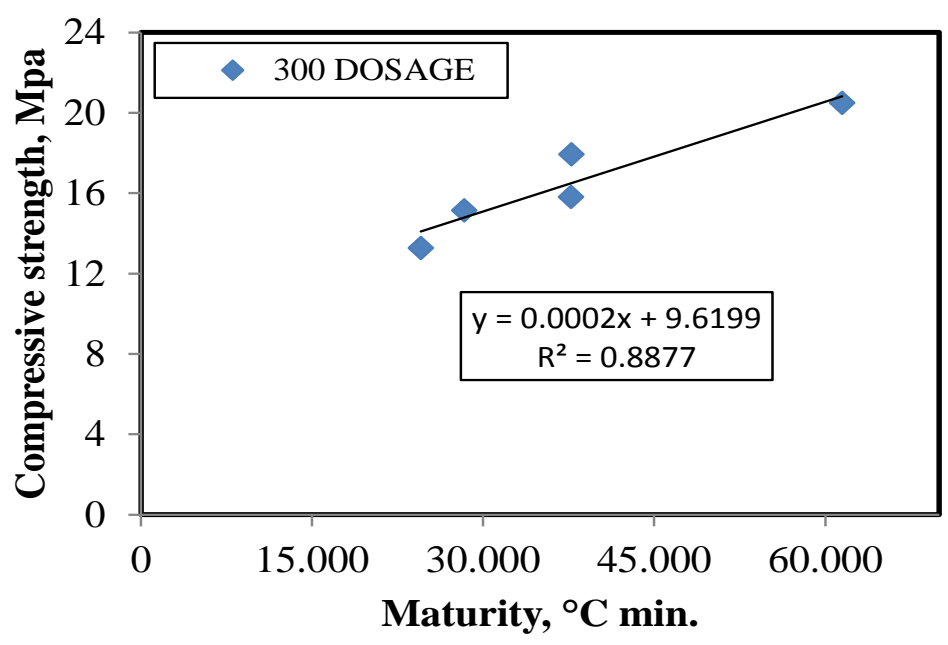


Figure 8. Relationship between maturity and 1 day compressive strength of concrete, $350 \mathrm{~kg} / \mathrm{m}^{3}$ cement. Source: Self-Elaboration.

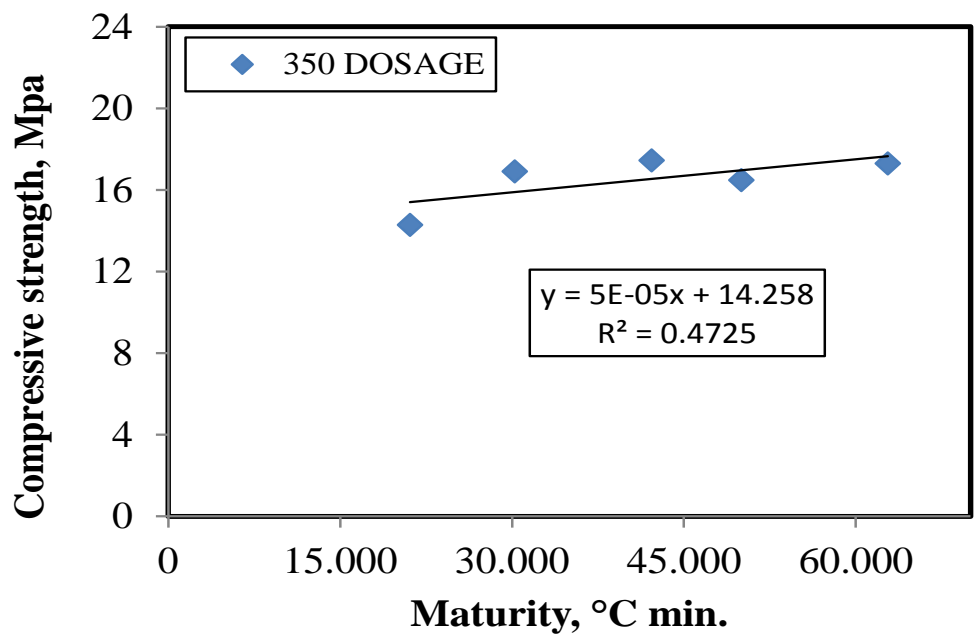

Figure 9. Relationship between maturity and 1 day compressive strength of concrete, $400 \mathrm{~kg} / \mathrm{m}^{3}$ cement Source: Self-Elaboration.

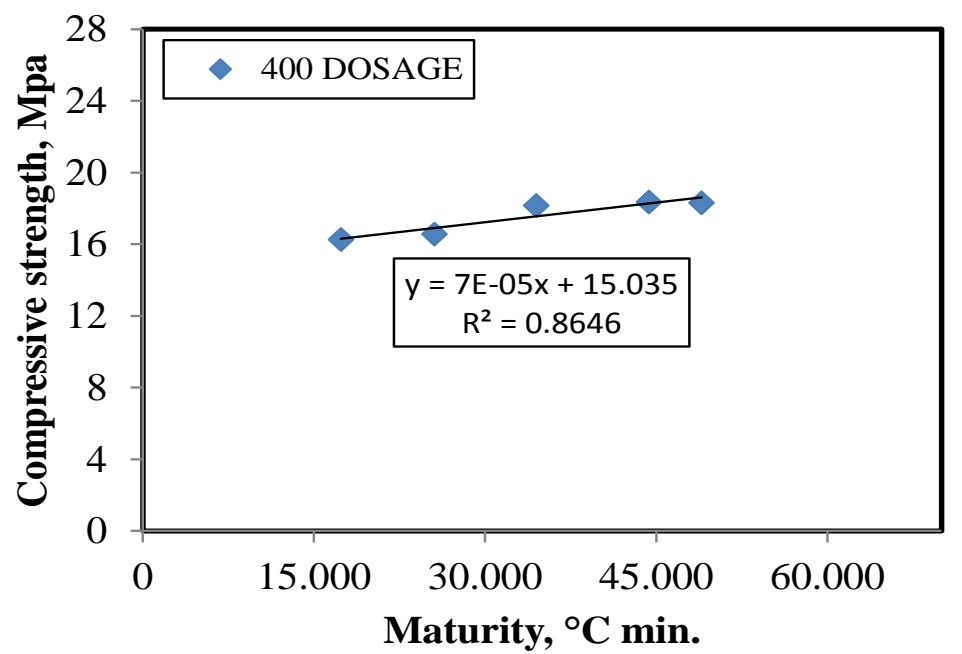

Table 3. Equation and correlation coefficient of different dosage concretes as a result of application of stress intensity. Source: Self-Elaboration.

\begin{tabular}{ccc}
\hline Dosage & Equation & $R^{2}$ \\
\hline 250 & $y=0.0003 x+5.6634$ & 0.9484 \\
300 & $y=0.0002 x+9.6199$ & 0.8877 \\
350 & $y=5 E-0.5 x+14.258$ & 0.4725 \\
400 & $y=7 E-0.5 x+15.035$ & 0.8646 \\
\hline
\end{tabular}

In order to find out the impact of cement content on 1 day (1440 minutes) maturity and compressive strength of the concrete, Figure 10 has been formed by intersecting maturity of concretes which have $250,300,350,400 \mathrm{~kg} / \mathrm{m}^{3}$ cement and to which $60 \mathrm{~V}$ voltage level applied with the compressive strength after 1 day. Consequently the increase of dosage (from 250 to 400) has caused increase in both maturity and 1 day compressive strength. This situation can be explained as follows related with the concrete to which $60 \mathrm{~V}$ voltage level was applied: as a result of increasing the amount of cement in concrete, the internal temperature of concrete has been increased. The relation between maturity and compressive strength of concretes which have $250,300,350,400 \mathrm{~kg} / \mathrm{m}^{3}$ cement has been demonstrated in Table 4.

Table 4. Relationship between maturity and compressive strength on the concretes to which $60 \mathrm{~V}$ voltage level was applied. Source: Self-Elaboration.

\begin{tabular}{ccc}
\hline Dosage & Maturity $\left({ }^{\circ} \mathrm{C} . \mathrm{min}.\right)$ & Compressive strength $(\mathrm{MPa})$ \\
\hline 250 & 35474 & 15.09 \\
300 & 37110 & 15.81 \\
350 & 42173 & 17.46 \\
400 & 47589 & 18.16 \\
\hline
\end{tabular}




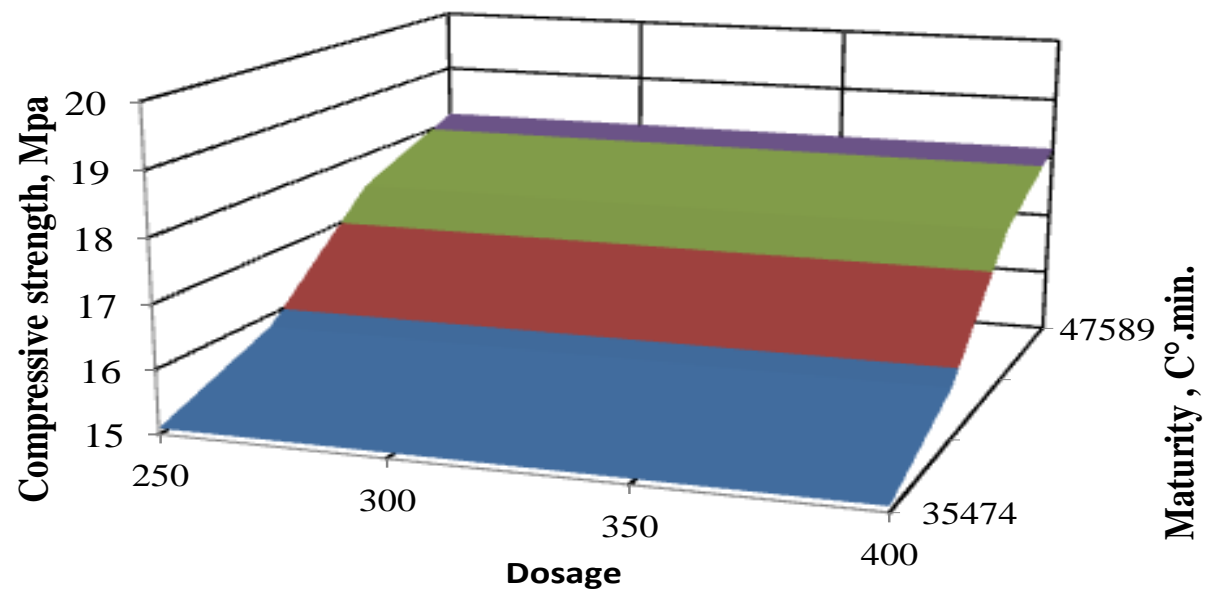

\section{The impact of internal temperature of concrete on compressive strength}

The most effective factor to determine mechanical properties of concrete is hydration temperature at the final setting time. Maturity is associated with age and internal temperature of concrete (Boubekeur, Ezziane, \& Kadri, 2014). As internal temperature of the concrete increases, the hydration reactions become quicker. Although hydration reactions accelerate until internal temperature of concrete increases to $100^{\circ} \mathrm{C}$, some researches show that the optimum value span of internal temperature of concrete is $45-50{ }^{\circ} \mathrm{C}$ without strength loss whereas higher internal temperatures cause strength loss (Neville \& Brooks, 1787). The most suitable internal temperature of concrete is determined as 100 ${ }^{0} \mathrm{~F}\left(38^{\circ} \mathrm{C}\right)$ in $\mathrm{ACl} 308$ standard $(\mathrm{ACl} 308,2001)$. Payá et al. (1995) examined the effect of hydration temperature $\left(20^{\circ} \mathrm{C}\right.$ $-80^{\circ} \mathrm{C}$ span) of cement based mortars to which fly ash was added by weight, on compressive strength. As a result, they found out that the most suitable optimum internal temperature of mortar is determined as $40{ }^{\circ} \mathrm{C}$ for puzzolonic reactions. In order to examine relation between the highest internal temperature of concrete and 1 day compressive strength as a result of $0 \mathrm{~V}, 40 \mathrm{~V}, 60 \mathrm{~V}, 80 \mathrm{~V}, 100 \mathrm{~V}$ AC current application to the concretes which have 250, 300, 350, $400 \mathrm{~kg} / \mathrm{m}^{3}$ cement (whose sizes are $10 \mathrm{~cm} \times 10 \mathrm{~cm} \times 35 \mathrm{~cm}$ ), Figure 11 has been formed. In general as the amount of cement in concretes and voltage level increase, compressive strength of concrete for 1 day increases too. 1 day compressive strength of the concretes which have 350 and $400 \mathrm{~kg} / \mathrm{m}^{3}$ cement decreases because of internal temperature takes very high values (such as $100{ }^{\circ} \mathrm{C}-110^{\circ} \mathrm{C}$ ). It can be explained through that internal temperatures of the concretes which have 350 and $400 \mathrm{~kg} / \mathrm{m}^{3}$ cement takes higher values than the internal temperature values of the concretes which have 250 and $300 \mathrm{~kg} / \mathrm{m}^{3}$ cement. Vaporization of surface water of the concretes which have 350 and $400 \mathrm{~kg} / \mathrm{m}^{3}$ cement is quicker than vaporization of the concretes which have 250 and $300 \mathrm{~kg} / \mathrm{m}^{3}$ cement. This situation is caused by vaporization of some of the water needed for hydration of cement. When the value of voltage level increases, the internal temperatures of concretes increase, as well. 1 day, 28 days and 180 days compressive strength of concretes which have $300 \mathrm{~kg} / \mathrm{m}^{3}$ cement and whose water/cement ratio is 0.65 have been examined in Figure 12 . For remaining days of 180 days specimens, specimens have been saved at room temperature. It is determined that one day compressive strength values of concretes to which current is applied are measured generally higher than the ones to which current isn't applied. As the value of voltage level increases, 1 day compressive strength increases, as well. This can be explained through the relation between the value of voltage level and hydration reactions since the increase in the value of voltage level accelerate hydration reactions. When 28 days compressive strength of concretes have been examined, it is shown that the value of voltage level has been increased. It is seen that compressive strength increases when $40 \mathrm{~V}$ and $60 \mathrm{~V}$ stress are applied but when $80 \mathrm{~V}$ and $100 \mathrm{~V}$ stress are applied, 28 days compressive strength decreases. When $80 \mathrm{~V}$ and $100 \mathrm{~V}$ current are applied to the concretes which have $300 \mathrm{~kg} / \mathrm{m}^{3}$ cement, 28 days compressive strength is decreased. This situation is caused by obtaining very high internal temperature in concretes when high degree of current such as $80 \mathrm{~V}$ and $100 \mathrm{~V}$ are applied. The highest value of compressive strength has been reached on 28 day concretes to which $40 \mathrm{~V}$ current are applied. This situation can be explained through achieving the closest optimum internal temperature value for the concrete when $40 \mathrm{~V}$ current is applied to the concretes which have $300 \mathrm{~kg} / \mathrm{m}^{3}$ cement (whose sizes are $10 \times 10 \times 35 \mathrm{~cm}$ ). For $80 \mathrm{~V}$ and higher voltage level values, decreases have been observed in 28 days compressive strength of concretes. When $80 \mathrm{~V}$ and higher voltage level are applied to the concretes which have $300 \mathrm{~kg} / \mathrm{m}^{3}$ cement, concrete's internal temperature takes very high values and this relation causes these decreases in 28 days compressive strength of concretes. In many studies, 
concrete's exposure to very high temperature at the beginning of hydration causes decreases in compressive strength in the long term since porosity occurs in cement matrixes (Frías Rojas, 2006; Maekawa, Ishida \& Kishi, 2009; Wang, Li $\& \mathrm{Xu}, 2017)$. When 180 days compressive strength on the concretes which have $300 \mathrm{~kg} / \mathrm{m}^{3}$ cement is examined, noticeable compressive strength loss on the concretes to which only $100 \mathrm{~V}$ voltage level is applied has been identified (Figure 12). Thus it can be said that internal temperature increases in concretes when high degree of current such as $100 \mathrm{~V}$ is applied. The maximum internal temperature of the concretes to which different amount of voltages levels applied are shown in Table 5.

Table 5. Maximum internal temperature ${ }^{\left({ }^{\circ} \mathrm{C}\right)} \begin{aligned} & \text { of the concretes to which different amount of voltages levels } \\
& \text { applied. Source: Self-Elaboration. }\end{aligned}$
\begin{tabular}{cccccc}
\multicolumn{5}{c}{ Voltage Level (V) } \\
\hline Dosage & $0 \mathrm{~V}$ & $40 \mathrm{~V}$ & $60 \mathrm{~V}$ & $80 \mathrm{~V}$ & $100 \mathrm{~V}$ \\
250 & 21.4 & 32.8 & 47.1 & 58 & 80.6 \\
300 & 27.2 & 33.9 & 52.2 & 78 & 99.4 \\
350 & 28.1 & 37.4 & 61.1 & 80.4 & 100.7 \\
400 & 30.4 & 47.4 & 71.5 & 97.1 & 104.7 \\
\hline
\end{tabular}

Figure 11. Relationship between the highest internal temperature of different dosage concretes and 1 day compressive strength. Source: Self-Elaboration.

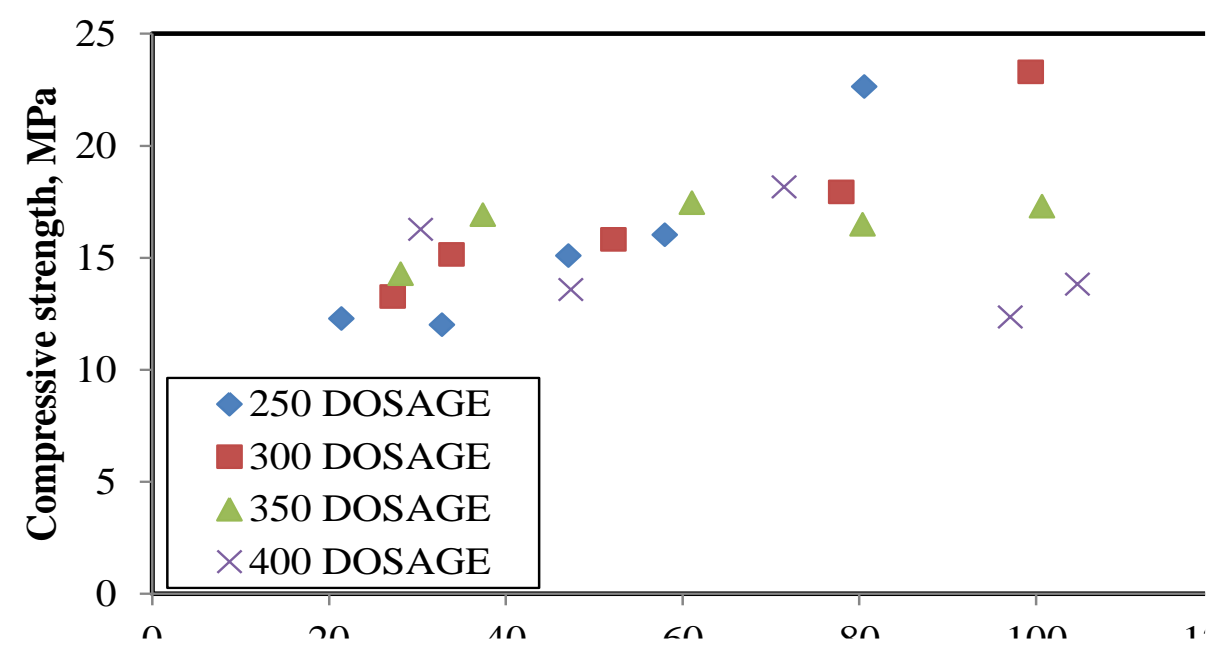

Figure 12. Change of compressive strength of the concretes which have $300 \mathrm{~kg} / \mathrm{m}^{3}$ cement on different days in terms of voltage level. Source: Self-Elaboration.

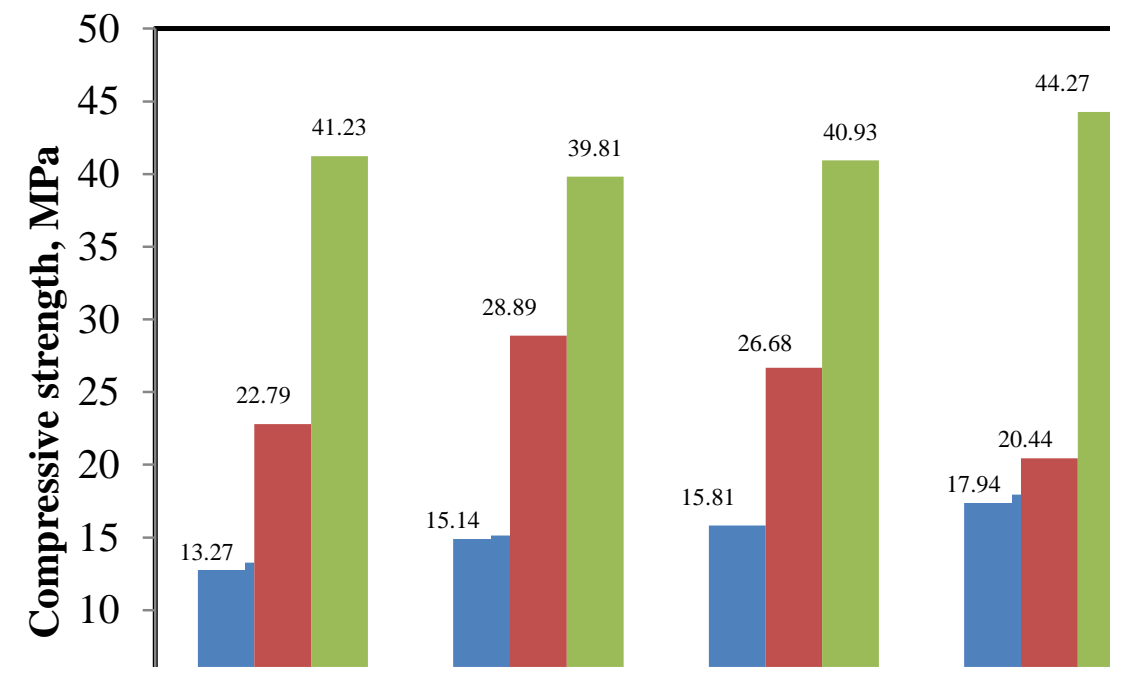




\section{Microstructure investigation of concrete}

During the hydration of cement based materials after mixing, calcium (Ca) and hydroxyl (OH) ions go into solution within the first $10 \mathrm{~min}$ (Engineering, 2015). After that, little happens except from a slow precipitation of semicrystalline calcium silicate hydrate gel $(\mathrm{C}-\mathrm{S}-\mathrm{H})$ while the calcium and hydroxyl ion concentrations continue to increase slowly (Buenfeld \& Newman, 1987; Li, Xiao \& Wei, 2007). The degree of hydration describes the process of hydration, and is directly associated with the fraction of the hydration products or porous structure in a hydration system in cement based materials (Levita, Marchetti, Gallone, Princigallo \& Guerrini, 2000). 180 days microstructure photos of the concretes which have $300 \mathrm{~kg} / \mathrm{m}^{3}$ cement, whose water/cement ratios are 0.65 and to which $0 \mathrm{~V}, 40 \mathrm{~V}, 60 \mathrm{~V}, 80 \mathrm{~V}$ and $100 \mathrm{~V}$ stress intensity is applied are shown in Figure 13. Scanning Electron Microscope (SEM) views have been zoomed to $5000 \times$. Hydration reactions have started to react in reference concrete as it is shown in Figure $13 a$. C-S-H gel plays the most important role in the engineering performances of concrete and other cementitious composites (Hu, Han, Gao, Zhang \& Li, 2014). For further demonstration of the connection between the composition and mechanical properties, the physical and mechanical parameters of C-S-H gels are connected through the micromechanical approach since most of the C-S-H gels belong to the $\mathrm{C}-\mathrm{S}-\mathrm{H} / \mathrm{CH}$ composite group (Hu, 2014). The most effective elements are Calcium (Ca) and Silisium (Si) during the construction of C-S-H gels. Higher $\mathrm{Ca} / \mathrm{Si}$ ratios of outer product and inner product of C-S-H gels indicate the effect of inclusions of other phases (Hu, 2014). It is determined that hydration reactions accelerate as stress intensity increases (from 0 to $100 \mathrm{~V}$ ). This situation can be explained as follows: when the stress intensity increases on concrete, internal temperature of concrete and the speed of hydration increase. It has been easily noticed that when $40 \mathrm{~V}$ stress is applied on concrete, it is seen that C-S-H gels have been occurred and the hydration reactions become quicker than reference concrete's hydration reaction speed (Figure 13b). It is seen that when $60 \mathrm{~V}, 80 \mathrm{~V}$ and $100 \mathrm{~V}$ stress is applied on concrete, C-S-H gels, CH composite and the hydration products have occurred much more (Figure 13c-13d-13e).

Figure 13. 180 days microstructure photos of the concretes which have $300 \mathrm{~kg} / \mathrm{m}^{3}$ cement a- $0 \mathrm{~V}, \mathrm{~b}-40 \mathrm{~V}, \mathrm{c}-60 \mathrm{~V}, \mathrm{~d}-80 \mathrm{~V}$, e-100 V. Source: Self-Elaboration.

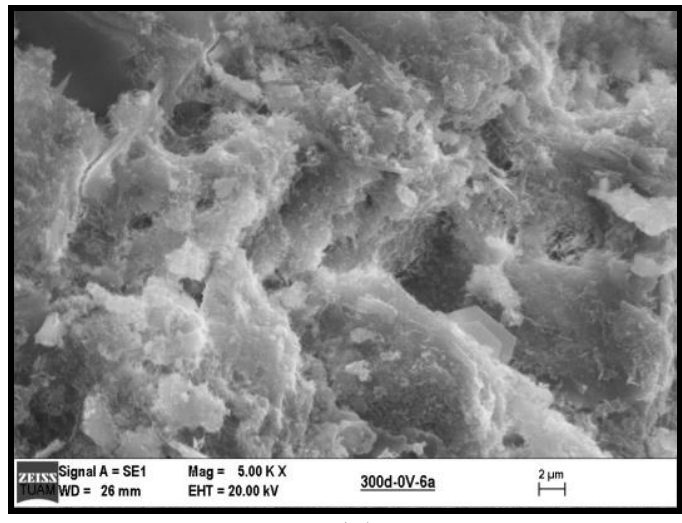

(a)

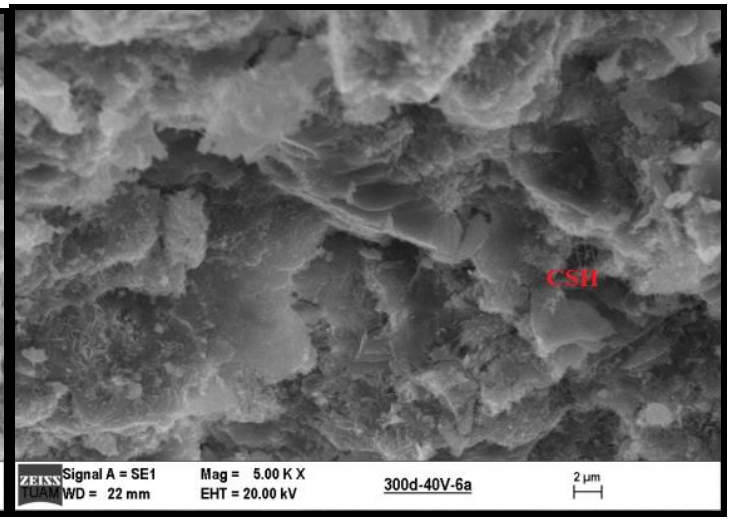

(b)

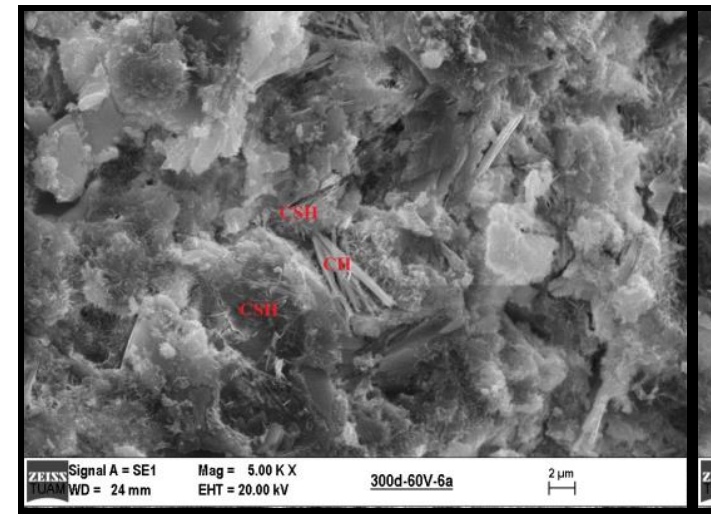

(c)

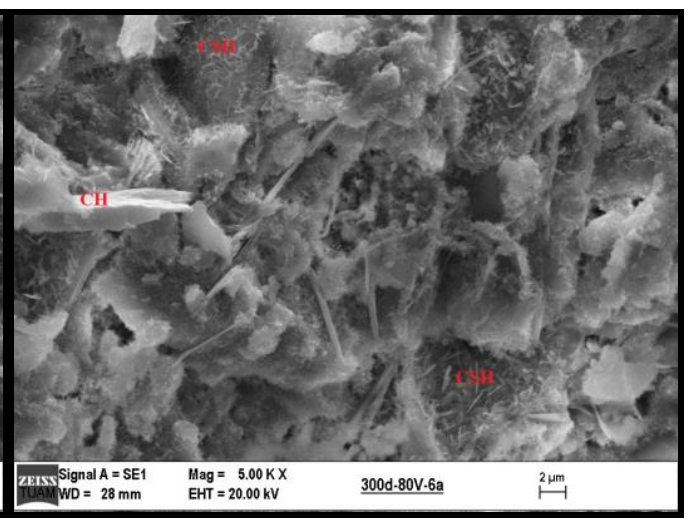

(d) 


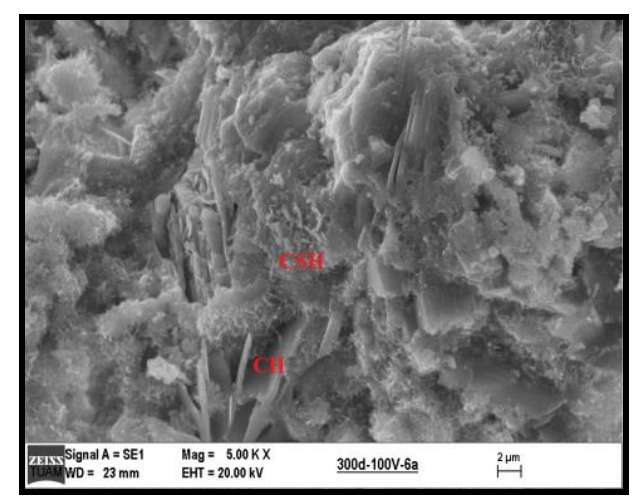

(e)

- Through increasing dosage of the cement (from 250 to 400) and voltage level on concretes, maturity of concretes increases. Hence concretes take high internal temperature with AC current application and through increasing amount of cement.

- Relationship between maturity and 1 day compressive strength of the concretes which have $250,300,350,400$ $\mathrm{kg} / \mathrm{m}^{3}$ cement can be estimated as using equation in Table 3 .

- It is found out that when voltage level increases (from 0 to $100 \mathrm{~V}$ ), maturity of concretes which have 250, 300, 350 and $400 \mathrm{~kg} / \mathrm{m}^{3}$ cement increases. The values of 1 day compressive strength of the concretes which have 250 , 300 and $350 \mathrm{~kg} / \mathrm{m}^{3}$ are higher than the one which has $400 \mathrm{~kg} / \mathrm{m}^{3}$. It can be explained that stress intensity for the concretes which have $400 \mathrm{~kg} / \mathrm{m}^{3}$ cement causes higher internal temperature values than the other dosages of cement in concretes.

- The value of 1 day compressive strength of concrete can be increased through applying AC current.

- It has been observed that when the amount of dosage and the value of stress intensity have been increased, 28 days of compressive strength of the concretes are decreased because of concretes internal temperature takes higher values.

- It is determined that the most suitable stress intensity is $40 \mathrm{~V}$ for 28 days compressive strength and $80 \mathrm{~V}$ for 180 days compressive strength.

- High maturity value of concrete is the indication of hydration degree. As a result of applying AC electrical current on concrete, hydration time can be shortened. In order to achieve the highest compressive strength for long term, application of logical voltage is required and as a result of this, suitable internal temperature is achieved.

- Consequently, maturity can be accelerated through increasing the amount of cement in concrete, applying AC stress to concrete and enhancing the value of voltage level, as well.

ACl Committee 308. (2001). Guide to Curing Concrete. American Concrete Institute Institute, 1-31. https://www.mendeley.com/catalogue/guidecuring-concrete/

ASTM Committee C09.64. (2015). ASTM C1074-11 Standard Practice for Estimating Concrete Strength by the Maturity Method. In Annual Book of ASTM Standards Volume 04.02 (p. 10). https://doi.org/10.1520/C1074-11

Benaicha, M., Burtschell, Y., \& Alaoui, A. H. (2016). Prediction of compressive strength at early age of concrete - Application of maturity. Journal of Building Engineering, 6, 119-125. https://doi.org/10.1016/j.jobe.2016.03.003

Bergstrom S.G. (1951). Curing temperature age and strength of concrete. Mag. Concr. Res., 5(14),61-66. https://doi.org/10.1680/macr.1953.5.14.61

Boubekeur, T., Ezziane, K., \& Kadri, E. H. (2014). Estimation of mortars compressive strength at different curing temperature by the maturity method. Computers and Chemical Engineering, 71, 299-307. https://doi.org/10.1016/j.conbuildmat.2014.08.084

Buenfeld, N. R., \& Newman, J. B. (1987). Examination of three methods for studying ion diffusion in cement pastes, mortars and concrete. Materials and Structures, 20(1), 3-10. https://doi.org/10.1007/BF02472720

Carino, N., \& Lew, H. (2001). The maturity method: from theory to application. Structures Congress and Exposition 2001, 1-19. https://doi.org/doi:10.1061/40558(2001)17

Çakir, Ö., \& Aköz, F. (2008). Effect of curing conditions on the mortars with and without GGBFS. Construction and Building Materials, 22(3), 308314. https://doi.org/10.1016/j.conbuildmat.2006.08.013 
Engineering, C. (2015). Bitumen surface energy characterization using a contact angle approach, 1561(May), 19426540. https://doi.org/10.1061/(ASCE)0899-1561(2006)18

Frías Rojas, M. (2006). Study of hydrated phases present in a MK-lime system cured at $60{ }^{\circ} \mathrm{C}$ and 60 months of reaction. Cement and Concrete Research, 36(5), 827-831. https://doi.org/10.1016/j.cemconres.2006.01.001

Frías, M. (2006). The effect of metakaolin on the reaction products and microporosity in blended cement pastes submitted to long hydration time and high curing temperature. Advances in Cement Research, 18(1), 1-6. https://doi.org/10.1680/adcr.2006.18.1.1

$\mathrm{Hu}, \mathrm{C}$. (2014). Microstructure and mechanical properties of fly ash blended cement pastes. Construction and Building Materials, 73, 618-625. https://doi.org/10.1016/j.conbuildmat.2014.10.009

$\mathrm{Hu}, \mathrm{C}$. (2014). Microstructure and mechanical properties of fly ash blended cement pastes. Construction and Building Materials, 73, 618-625. https://doi.org/10.1016/j.conbuildmat.2014.10.009

Hu, C., Han, Y., Gao, Y., Zhang, Y., \& Li, Z. (2014). Property investigation of calcium-silicate-hydrate (C-S-H) gel in cementitious composites. Materials Characterization, 95, 129-139. https://doi.org/10.1016/j.matchar.2014.06.012

Kjellsen, K. O., Detwiler, R. J., \& Gjørv, O. E. (1990). Pore structure of plain cement pastes hydrated at different temperatures. Cement and Concrete Research, 20(6), 927-933. https://doi.org/10.1016/0008-8846(90)90055-3

Wang, P., Li, N., \& Xu, L. (2017). Hydration evolution and compressive strength of calcium sulphoaluminate cement constantly cured over the temperature range of 0 to 80 C. Cement and Concrete Research, 45, 204-213. https://doi.org/10.1016/j.cemconres.2017.05.025

Laplante P., Roussel S., Lecrux S. (1998). Technique maturométrique: la loi d'Arrhénius au service des chantiers. Proceedings of the International RILEM Conference, RILEM Publications, Arles, France, 323-342. http://cdoc.ensm-douai.fr/EMDcat/DetailDoc.aspx?DocID=160801

Levita, G., Marchetti, A., Gallone, G., Princigallo, A., \& Guerrini, G. L. (2000). Electrical properties of fluidified Portland cement mixes in the early stage of hydration. Cement and Concrete Research, 30(6), 923-930. https://doi.org/10.1016/S0008-8846(00)00282-9

Li, Z., Xiao, L., \& Wei, X. (2007). Determination of concrete setting time using electrical resistivity measurement. Journal of Materials in Civil Engineering, 19(5), 423-427. https://doi.org/10.1061/(ASCE)0899-1561(2007)19:5(423)

Maekawa K., Ishida T., Kishi T. (2009). Multi-scale Modeling of Structural Concrete. Taylor \& Francis, London. https://books.google.com.tr/books?id=JE4P4srh_QC\&lpg=PP1\&ots=QlxhB5hLoB\&dq=multiscale\%20modeling\%20of\%20structural\%20concret e\&lr\&hl=tr\&pg=PP1\#v=twopage \& \&f=false

Massazza F., Daimond M. (1992). Chemistry of hydration of cements and cementitious systems. National council for cement and building materials. Proceedings of ninth international congress on the chemistry of cement, India, 1, 383-448. https://catalog.hathitrust.org/Record/009223995

Neville, A.M and Brooks, J.J. (1787). Concrete technology. Longman Scientific and Technical, John Wiley and Sons. Inc, New York. https://docslide.com.br/documents/concrete-construction.html

Payá, J., Monzó, J., Borrachero, M. V., \& Peris-Mora, E. (1995). Mechanical treatment of fly ashes. Part I: Physico-chemical characterization of ground fly ashes. Cement and Concrete Research, 25(7), 1469-1479. https://doi.org/10.1016/0008-8846(95)00141-X

Saul A.G.A. (1951). Principles underlying the steam curing of concrete at atmospheric pressure. Mag. Concr. Res., 2(6),127-140. https://doi.org/10.1680/macr.1951.2.6.127

Topcu, I. B., Uygunolu, T., \& Hocaolu, I. (2012). Electrical conductivity of setting cement paste with different mineral admixtures. Construction and Building Materials, 28(1), 414-420. https://doi.org/10.1016/j.conbuildmat.2011.08.068

TS EN 933-2 (2013). Test for Geometrical Properties of Aggregates-Part 2: Determination of Particle Size Distribution-Test Sieves, Nominal Size of Apartures. Turkish Standard Institute, Ankara, Turkey. https://www.mendeley.com/catalogue/en-9332-tests-geometrical-propertiesaggregates/

Uygunoğlu, T., \& Hocaoğlu, i. (2018). Effect of electrical curing application on setting time of concrete with different stress intensity. Construction and Building Materials, 162, 298-305. https://doi.org/10.1016/j.conbuildmat.2017.12.036

Wang, X. Y., \& Park, K. B. (2017). Analysis of the compressive strength development of concrete considering the interactions between hydration and drying. Cement and Concrete Research, 102(2016), 1-15. https://doi.org/10.1016/j.cemconres.2017.08.010

Xuan, D., Zhan, B., \& Poon, C. S. (2018). A maturity approach to estimate compressive strength development of CO2-cured concrete blocks. Cement and Concrete Composites, 85, 153-160. https://doi.org/10.1016/j.cemconcomp.2017.10.005 